\title{
Blood eosinophil count, a marker of inhaled corticosteroid effectiveness in preventing COPD exacerbations in post-hoc RCT and observational studies: systematic review and meta-analysis
}

Timothy H. Harries ${ }^{1 *}$ (D), Victoria Rowland ${ }^{1}$, Christopher J. Corrigan², lain J. Marshall', Lucy McDonnell', Vibhore Prasad', Peter Schofield', David Armstrong ${ }^{1}$ and Patrick White ${ }^{1}$

\begin{abstract}
Background: Blood eosinophil count has been proposed as a predictor of response to inhaled corticosteroid (ICS) in the prevention of acute exacerbations of COPD. An optimal threshold of blood eosinophil count for prescribing ICS has not been agreed. Doubt has been cast on the role by observational studies. The role of inhaled corticosteroids in this relationship, independent of long-acting bronchodilators, has not been examined.

Methods: We conducted a systematic review of post-hoc analyses of randomised controlled trials (RCTs) and observational studies examining three blood eosinophil thresholds and the independent role of ICS. Included studies were categorised by the form (relative or absolute count) and cut point of eosinophil threshold used. Thresholds assessed were relative eosinophil count of $2 \%$, and absolute counts of 150 cells/ $\mu \mathrm{L}$ and $300 \mathrm{cells} / \mathrm{\mu L}$. Three meta-analyses of the effect of ICS use in post-hoc analyses of RCTs based on these counts were carried out. Initial analysis included all studies of ICS vs. any non-ICS regimen. Further analysis examined the effect of ICS, independent of the effect of long-acting bronchodilators.

Results: Sixteen studies examined the association between blood eosinophil count and response of exacerbation risk to ICS, in COPD patients. Eleven studies (25,881 patients) were post-hoc analyses of RCTs. Five studies (109,704 patients) were retrospective observational studies. The independent effect of ICS on the reduction of exacerbation risk was $20 \%$ at $\geq 2 \%$ blood eosinophil threshold (RR, 0.80; $95 \%$ Cl, 0.74-0.85), 35\% at $\geq 150$ cells/ $\mu \mathrm{L}$ blood eosinophil threshold (RR, 0.65; 0.52-0.79), and 39\% at $\geq 300$ cells/ $\mu \mathrm{L}$ blood eosinophil threshold (RR, $0.61 ; 0.44-0.78$ ). No association was found in four out of five observational studies.
\end{abstract}

Conclusion: This is the first systematic review to assess, in post-hoc analyses of RCTs, the independent effect of ICS in reducing the risk of COPD exacerbation across a range of blood eosinophil thresholds. Association between ICS prescription and reduced exacerbation risk at these thresholds was confirmed. The lack of association found in the observational studies questions the relevance of these observations to a "real world" COPD population. To clarify the clinical utility of this biomarker, the association should be tested in prospective effectiveness studies.

Keywords: Pulmonary disease, chronic obstructive, Eosinophils, Inhaled corticosteroids, Randomised controlled trials, Observational studies

\footnotetext{
* Correspondence: timothy.harries@kcl.ac.uk

'Department of Public Health and Primary Care, School of Population Health

\& Environmental Sciences, King's College London, 3rd floor Addison House,

Guys Campus, London SE1 1UL, UK

Full list of author information is available at the end of the article
}

(c) The Author(s). 2020 Open Access This article is distributed under the terms of the Creative Commons Attribution 4.0 International License (http://creativecommons.org/licenses/by/4.0/), which permits unrestricted use, distribution, and reproduction in any medium, provided you give appropriate credit to the original author(s) and the source, provide a link to the Creative Commons license, and indicate if changes were made. The Creative Commons Public Domain Dedication waiver (http://creativecommons.org/publicdomain/zero/1.0/) applies to the data made available in this article, unless otherwise stated. 


\section{Introduction}

Inhaled corticosteroid (ICS) therapy has been reported to be associated with a reduction in the risk of moderate and severe exacerbations in a subgroup of patients with chronic obstructive pulmonary disease (COPD) [1]. Those COPD patients with predominantly eosinophilic airways inflammation [2] may derive the most benefit from ICS use [3-7]. International guidelines reflect this targeted approach to ICS prescription [8]. The peripheral blood eosinophil count, absolute and relative, has high correlation with sputum eosinophils [9] and has gained increased recognition as a proxy of eosinophilic airways inflammation [10]. In one stable state COPD population $37.4 \%$ of patients had a blood eosinophil count of $\geq 2 \%$ [11]. This threshold may predict response to ICS treatment with respect to modification of exacerbation risk in COPD patients [12]. Evidence for this association has been derived from post-hoc analyses of randomised controlled trials (RCTs) [10]. High rates of prescription of ICS, outside guidelines, highlight the importance of targeted prescribing for patients with COPD. In primary care in England, 24\% of COPD patients were prescribed ICS and long-acting beta-agonists (LABA) outside of the 2011 Global Initiative for Chronic Obstructive Lung Disease (GOLD) guidelines [13]. Between 2007 and 2010, large increases in ICS prescribing were not associated with expected impact on the incidence of admissions for exacerbations $[14,15]$.

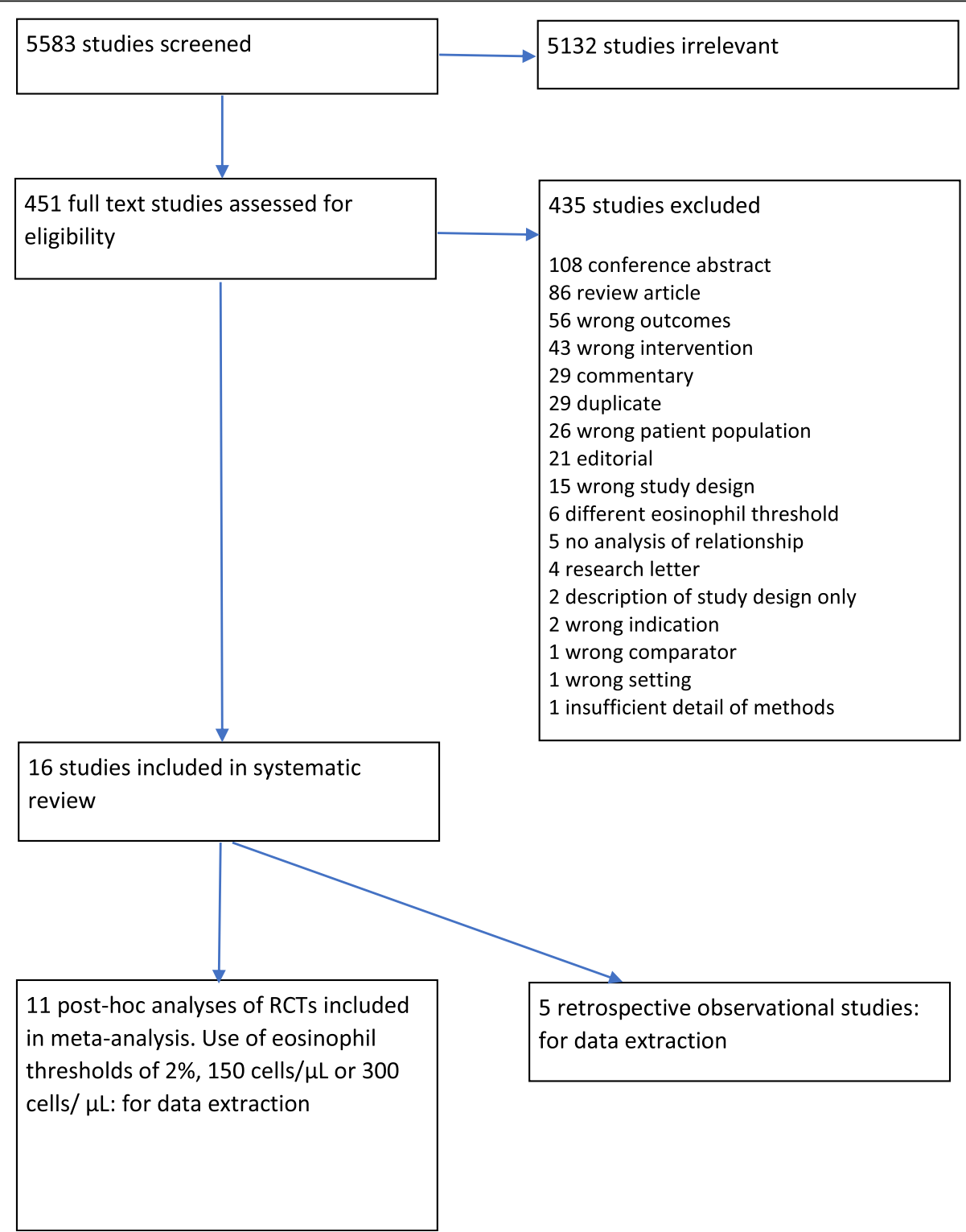

Fig. 1 PRISMA (Preferred Reporting Items for Systematic Reviews and Meta-Analysis) flow chart 
Table 1 Characteristics of included post-hoc analyses of RCTs for meta-analysis

\begin{tabular}{|c|c|c|c|c|c|}
\hline Author & Study design & $\begin{array}{l}\text { Study size (eosinophil } \\
\text { data available) }\end{array}$ & Study arms & $\begin{array}{l}\text { Eosinophil count } \\
\text { subgroups }\end{array}$ & $\begin{array}{l}\text { ICS effect } \\
\text { isolated }\end{array}$ \\
\hline $\begin{array}{l}\text { Pascoe et al. } \\
\text { [20] } 2015\end{array}$ & $\begin{array}{l}\text { Two replicate double-blind, } \\
\text { parallel group RCTs. Patients } \\
\text { were treated with } 25 \mu \mathrm{g} \\
\text { vilanterol alone, or } 25 \mu \mathrm{g} \\
\text { vilanterol combined with } \\
50 \mu \mathrm{g}, 100 \mu \mathrm{g} \text { or } 200 \mu \mathrm{g} \\
\text { fluticasone }\end{array}$ & $\begin{array}{l}3177 \text { patients (799 } \\
\text { in } 25 \mu \mathrm{g} \text { vilanterol } \\
\text { alone group, } 2378 \\
\text { in fluticasone }+ \\
\text { vilanterol groups) }\end{array}$ & $\begin{array}{l}\text { Fluticasone + vilanterol } \\
\text { (all doses) vs. vilanterol }\end{array}$ & 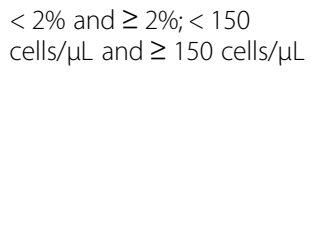 & Yes \\
\hline $\begin{array}{l}\text { Barnes et al. [25] } \\
\text { (ISOLDE) } 2016\end{array}$ & $\begin{array}{l}\text { Double-blind, parallel } \\
\text { group, placebo- } \\
\text { controlled RCT. Patients } \\
\text { were treated with } \\
500 \mu \text { fluticasone } \\
\text { twice daily or placebo. }\end{array}$ & $\begin{array}{l}742 \text { patients ( } 370 \\
\text { fluticasone group, } \\
372 \text { placebo group). }\end{array}$ & Fluticasone vs. placebo & $<2 \%$ and $\geq 2 \%$ & Yes \\
\hline $\begin{array}{l}\text { Pavord et al. [26] } \\
\text { (INSPIRE) } 2016\end{array}$ & $\begin{array}{l}\text { Double-blind, double- } \\
\text { dummy, parallel-group } \\
\text { RCT. Patients were } \\
\text { treated with } 500 \mu \mathrm{gg} \\
\text { fluticasone }+50 \mu \mathrm{g} \\
\text { salmeterol or } 18 \mu \mathrm{g} \\
\text { tiotropium }\end{array}$ & $\begin{array}{l}1269 \text { patients ( } 634 \\
\text { fluticasone }+ \\
\text { salmeterol group, } \\
635 \text { tiotropium group) }\end{array}$ & $\begin{array}{l}\text { Fluticasone + salmeterol } \\
\text { vs. Tiotropium }\end{array}$ & $<2 \%$ and $\geq 2 \%$ & No \\
\hline $\begin{array}{l}\text { Pavord et al. [26] } \\
\text { (TRISTAN I) } 2016\end{array}$ & $\begin{array}{l}\text { Double-blind, parallel- } \\
\text { group RCT. Patients } \\
\text { were treated with } \\
500 \mu \mathrm{g} \text { fluticasone } \\
+50 \mu \mathrm{g} \text { salmeterol } \\
\text { or } 50 \mathrm{\mu g} \text { salmeterol }\end{array}$ & $\begin{array}{l}696 \text { patients ( } 341 \\
\text { fluticasone }+ \\
\text { salmeterol group, } \\
355 \text { salmeterol group) }\end{array}$ & $\begin{array}{l}\text { Fluticasone + salmeterol } \\
\text { vs. salmeterol }\end{array}$ & $<2 \%$ and $\geq 2 \%$ & Yes \\
\hline $\begin{array}{l}\text { Pavord et al. [26] } \\
\text { (TRISTAN II) } 2016\end{array}$ & $\begin{array}{l}\text { Double-blind, parallel- } \\
\text { group, placebo- } \\
\text { controlled RCT. Patients } \\
\text { were treated with } \\
500 \mu \text { fluticasone } \\
\text { or placebo }\end{array}$ & $\begin{array}{l}707 \text { patients (360 } \\
\text { fluticasone group, } \\
347 \text { placebo group) }\end{array}$ & Fluticasone vs. placebo & $<2 \%$ and $\geq 2 \%$ & Yes \\
\hline $\begin{array}{l}\text { Pavord et al. [26] } \\
\text { (SCO30002) } 2016\end{array}$ & $\begin{array}{l}\text { Double-blind, parallel-group, } \\
\text { placebo-controlled RCT. } \\
\text { Patients were treated with } \\
500 \text { mg fluticasone or placebo }\end{array}$ & $\begin{array}{l}244 \text { patients ( } 124 \\
\text { fluticasone group, } \\
120 \text { placebo group) }\end{array}$ & Fluticasone vs. placebo & $<2 \%$ and $\geq 2 \%$ & Yes \\
\hline $\begin{array}{l}\text { Watz et al. [27] } \\
\text { (WISDOM) } 2016\end{array}$ & $\begin{array}{l}\text { Double-blind, parallel-group } \\
\text { RCT. Patients treated with } \\
18 \mu \mathrm{g} \text { tiotropium daily plus } \\
500 \mu \mathrm{g} \text { fluticasone }+50 \mu \mathrm{g} \\
\text { salmeterol twice daily for } \\
6 \text { weeks. Then randomised } \\
\text { to withdrawal of fluticasone } \\
\text { or continued triple therapy. }\end{array}$ & $\begin{array}{l}2296 \text { patients ( } 1144 \\
\text { ICS-continuation } \\
\text { group, } 1152 \text { ICS- } \\
\text { withdrawal group) }\end{array}$ & $\begin{array}{l}\text { Fluticasone + tiotropium } \\
\text { + salmeterol vs. tiotropium } \\
\text { + salmeterol }\end{array}$ & 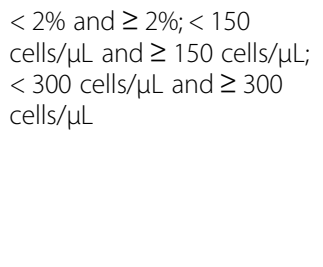 & Yes \\
\hline $\begin{array}{l}\text { Papi et al. [28] } \\
\text { (EFFECT) } 2017\end{array}$ & $\begin{array}{l}\text { Double-blind, parallel-group } \\
\text { RCT. Patients were treated } \\
\text { with } 500 \mu \mathrm{g} \text { fluticasone } \\
+20 \mu \mathrm{g} \text { formoterol twice } \\
\text { daily or formoterol } 12 \mu \mathrm{g} \\
\text { twice daily. }\end{array}$ & $\begin{array}{l}1177 \text { patients ( } 587 \\
\text { fluticasone + } \\
\text { formoterol group, } \\
590 \text { formoterol group) }\end{array}$ & $\begin{array}{l}\text { Fluticasone + formoterol } \\
\text { vs. formoterol }\end{array}$ & $<2 \%$ and $\geq 2 \%$ & Yes \\
\hline $\begin{array}{l}\text { Vestbo et al. [29] } \\
\text { (TRINITY) } 2017\end{array}$ & $\begin{array}{l}\text { Double-blind, parallel-group } \\
\text { RCT. Patients were treated } \\
\text { with } 100 \mu \mathrm{g} \text { beclometasone } \\
+6 \mu \mathrm{g} \text { formoterol }+12.5 \mu \mathrm{g} \\
\text { glycopyrronium two puffs } \\
\text { twice daily or } 18 \mu \mathrm{g} \\
\text { tiotropium }\end{array}$ & $\begin{array}{l}2153 \text { patients (1077 } \\
\text { fixed triple group, } \\
1076 \text { tiotropium } \\
\text { group) }\end{array}$ & $\begin{array}{l}\text { Beclometasone + } \\
\text { formoterol + } \\
\text { glycopyrronium vs. } \\
\text { tiotropium }\end{array}$ & $<2 \%$ and $\geq 2 \%$ & No \\
\hline $\begin{array}{l}\text { Roche et al. [30] } \\
\text { (FLAME) } 2017\end{array}$ & $\begin{array}{l}\text { Double-blind, parallel-group } \\
\text { RCT. Patients were treated } \\
\text { with } 500 \mu \mathrm{g} \text { fluticasone } \\
+50 \mu \mathrm{\mu g} \text { salmeterol twice } \\
\text { daily or } 110 \mu \mathrm{g} \text { indacaterol }\end{array}$ & $\begin{array}{l}3349 \text { patients ( } 1677 \\
\text { fluticasone + } \\
\text { salmeterol group, } \\
1672 \text { indacaterol + } \\
\text { glycopyrronium group) }\end{array}$ & $\begin{array}{l}\text { Fluticasone + salmeterol } \\
\text { vs. indacaterol + } \\
\text { glycopyrronium }\end{array}$ & 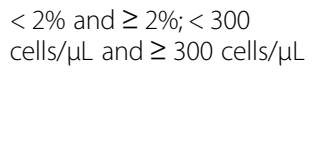 & No \\
\hline
\end{tabular}


Table 1 Characteristics of included post-hoc analyses of RCTs for meta-analysis (Continued)

\begin{tabular}{|c|c|c|c|c|c|}
\hline Author & Study design & $\begin{array}{l}\text { Study size (eosinophil } \\
\text { data available) }\end{array}$ & Study arms & $\begin{array}{l}\text { Eosinophil count } \\
\text { subgroups }\end{array}$ & $\begin{array}{l}\text { ICS effect } \\
\text { isolated }\end{array}$ \\
\hline & $\begin{array}{l}+50 \mu \mathrm{g} \text { glycopyrronium } \\
\text { once a day }\end{array}$ & & & & \\
\hline $\begin{array}{l}\text { Chapman et al. [31] } \\
\text { (SUNSET) } 2018\end{array}$ & $\begin{array}{l}\text { Double-blind, triple-dummy, } \\
\text { parallel-group RCT. Patients } \\
\text { were treated with } 18 \mu \mathrm{g} \\
\text { tiotropium once daily plus } \\
500 \mu \mathrm{g} \text { fluticasone }+50 \mu \mathrm{g} \\
\text { salmeterol twice daily or } \\
110 \mu \mathrm{g} \text { indacaterol }+50 \mu \mathrm{gg} \\
\text { glycopyrronium once a day }\end{array}$ & $\begin{array}{l}1051 \text { patients ( } 526 \\
\text { fluticasone + salmeterol } \\
\text { + tiotropium group, } \\
527 \text { indacaterol + } \\
\text { glycopyrronium group) }\end{array}$ & $\begin{array}{l}\text { Fluticasone + tiotropium } \\
+ \text { salmeterol vs. indacaterol } \\
+ \text { glycopyrronium }\end{array}$ & $\begin{array}{l}<2 \% \text { and } \geq 2 \% ;<300 \\
\text { cells/ } \mu \mathrm{L} \text { and } \geq 300 \text { cells } / \mu \mathrm{L}\end{array}$ & Yes \\
\hline $\begin{array}{l}\text { Papi et al. [32] } \\
\text { (TRIBUTE) } 2018\end{array}$ & $\begin{array}{l}\text { Double-blind, double- } \\
\text { dummy, parallel-group } \\
\text { RCT. Patients were treated } \\
\text { with } 87 \mu \mathrm{g} \text { beclometasone } \\
+5 \mu \mathrm{g} \text { formoterol }+9 \mu \mathrm{g} \\
\text { glycopyrronium two } \\
\text { puffs twice daily or } 85 \mu \mathrm{g} \\
\text { indacaterol }+43 \mu \mathrm{g} \\
\text { glucopyrronium once } \\
\text { a day }\end{array}$ & $\begin{array}{l}1532 \text { patients (764 } \\
\text { BDP/FF/G, } 768 \text { IND/GLY) }\end{array}$ & $\begin{array}{l}\text { Beclometasone/formoterol/ } \\
\text { glycopyrronium vs. } \\
\text { indacaterol/ glycopyrronium }\end{array}$ & $<2 \%$ and $\geq 2 \%$ & Yes \\
\hline $\begin{array}{l}\text { Ferguson et al. [33] } \\
\text { (KRONOS) } 2018\end{array}$ & $\begin{array}{l}\text { Double-blind, parallel- } \\
\text { group RCT. Patients were } \\
\text { treated with } 320 \mu \mathrm{\mu g} \\
\text { budesonide }+18 \mu \mathrm{g} \\
\text { glycopyrolate }+9.6 \mu \mathrm{gg} \\
\text { formoterol two puffs } \\
\text { twice daily or } 18 \mu \mathrm{gg} \\
\text { glycopyrolate }+9.6 \mu \mathrm{gg} \\
\text { formoterol two puffs } \\
\text { twice daily }\end{array}$ & $\begin{array}{l}1267 \text { patients ( } 640 \\
\text { BGF, } 627 \text { GFF) }\end{array}$ & $\begin{array}{l}\text { Budesonide/glycopyrolate/ } \\
\text { formoterol vs. glycopyrolate/ } \\
\text { formoterol }\end{array}$ & $\begin{array}{l}<150 \text { cells } / \mu \mathrm{L} \text { and } \\
\geq 150 \text { cells } / \mu \mathrm{L}\end{array}$ & Yes \\
\hline $\begin{array}{l}\text { Lipson et al. [34] } \\
\text { (IMPACT) } 2018\end{array}$ & $\begin{array}{l}\text { Double-blind, parallel- } \\
\text { group RCT. Patients were } \\
\text { treated with } 100 \mu \mathrm{g} \\
\text { fluticasone }+62.5 \mu \mathrm{g} \\
\text { umeclidinium }+25 \mu \mathrm{g} \\
\text { vilanterol once daily or } \\
62.5 \mu \mathrm{g} \text { umeclidinium } \\
+25 \mu \mathrm{g} \text { vilanterol once } \\
\text { daily }\end{array}$ & $\begin{array}{l}6221 \text { patients ( } 4151 \\
\text { triple therapy, } 2070 \\
\text { umeclidinium + } \\
\text { vilanterol) }\end{array}$ & $\begin{array}{l}\text { Fluticasone furoate/ } \\
\text { umeclidinium/ vilanterol } \\
\text { vs. umeclidinium/vilanterol }\end{array}$ & $\begin{array}{l}<150 \text { cells } / \mu \mathrm{L} \text { and } \\
\geq 150 \mathrm{cells} / \mu \mathrm{L}\end{array}$ & Yes \\
\hline
\end{tabular}

The stability of the blood eosinophil count has been questioned, raising doubts about the appropriateness of using a single measurement as a reliable predictor of ICS response [16]. A cohort study of COPD patients with moderate airflow limitation did not find a relationship between numbers of tissue eosinophils in the airways and lung parenchyma and blood eosinophils [17]. Studies examining the role of blood eosinophils as a biomarker of ICS sensitivity have selected different thresholds of relative and absolute counts in their analyses. Previous reviews, in their comparisons of the impact on exacerbation risk of ICS vs. non-ICS, have not isolated the effect of the ICS from that of bronchodilators [7, 12]. A recent systematic review examined the impact of triple therapy vs. dual bronchodilator therapy among patients with blood eosinophilia but did not stratify the studies by eosinophil threshold [6]. An assessment of blood eosinophil count as a marker of the independent effect of ICS on reduction of exacerbation frequency would help to clarify the value of this biomarker as a guide to the prescription of these drugs.

We have chosen three thresholds as likely markers of corticosteroid-responsive disease. An association has been found between blood eosinophil counts of $\geq 2 \%$ and an increased risk of severe exacerbations and mortality from exacerbations among patients with COPD [18]. The benefits of oral corticosteroids have been found only in those patients with blood eosinophils of $\geq 2 \%$ [19]. A correlation has been reported between a relative blood eosinophil count of $2 \%$ and an absolute blood eosinophil count of 150 cells/ $\mu \mathrm{L}$ [20]. The GOLD guidelines recommend the use of an absolute blood eosinophil count of $\geq 300$ cells/ $\mu \mathrm{L}$ to identify patients with COPD who should escalate their treatment from use of long-acting betaagonist + long-acting muscarinic antagonist (LABA+LAMA) to use of LABA+ICS [8]. This systematic review 


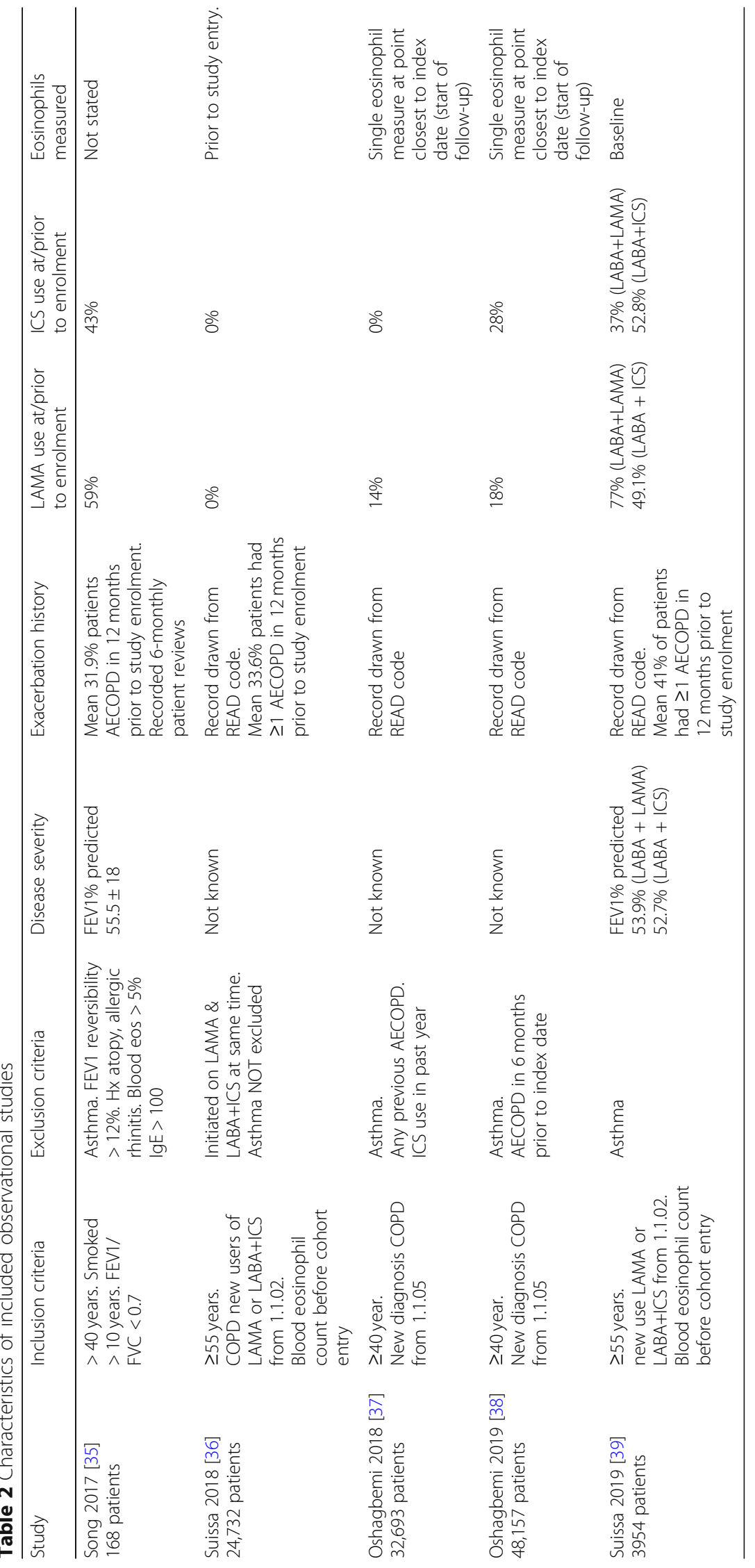


provides an up-to-date analysis of the predictive value of three blood eosinophil thresholds $(2 \%, 150$ cells $/ \mu \mathrm{L}$, and 300 cells $/ \mu \mathrm{L}$ ) as biomarkers of the independent impact of ICS use on the risk of moderate and severe exacerbations in COPD patients. These findings are compared to those of real-world observational studies.

\section{Methods}

The population of this review were patients with COPD stratified by blood eosinophil count. Blood eosinophil thresholds of $2 \%, 150$ cells $/ \mu \mathrm{L}$, and 300 cells $/ \mu \mathrm{L}$ were examined. The intervention was the use of inhaled corticosteroids at any dosage. The comparison was the use of ICS with any non-ICS combination inhaler or placebo (all association studies). A separate analysis examined the independent effect of ICS by comparing use of ICS monotherapy vs. placebo, or ICS + LABA vs. LABA, or ICS + LABA+LAMA vs. LABA+LAMA (ICS-independent association studies). The outcome was the risk of moderate or severe exacerbations of COPD. The report follows the Preferred Reporting Items for
Systematic Reviews and Meta-analyses Statement (PRISMA) guidelines [21].

\section{Search strategy}

Searches were made of five electronic databases from inception to 10/7/19: Medline, Cochrane Central Register of Controlled Trials, CINAHL, Embase, Web of Science. Literature search strategies were developed using medical subject headings $(\mathrm{MeSH})$ and free text corresponding to obstructive airways disease, COPD, inhaled corticosteroids and eosinophils.

The web-based software Covidence was used to facilitate the screening and selection of studies. The first author (THH) conducted the database searches, removed duplicates and screened titles and abstracts of retrieved papers with respect to the eligibility criteria. Two reviewers (THH, VR) independently assessed the full text articles for eligibility. Any disagreements were resolved by discussion. If consensus was not reached, a third reviewer (PW) moderated the decision. Reasons for exclusion of full text articles were clearly recorded. Two reviewers (THH \& PW) independently conducted a

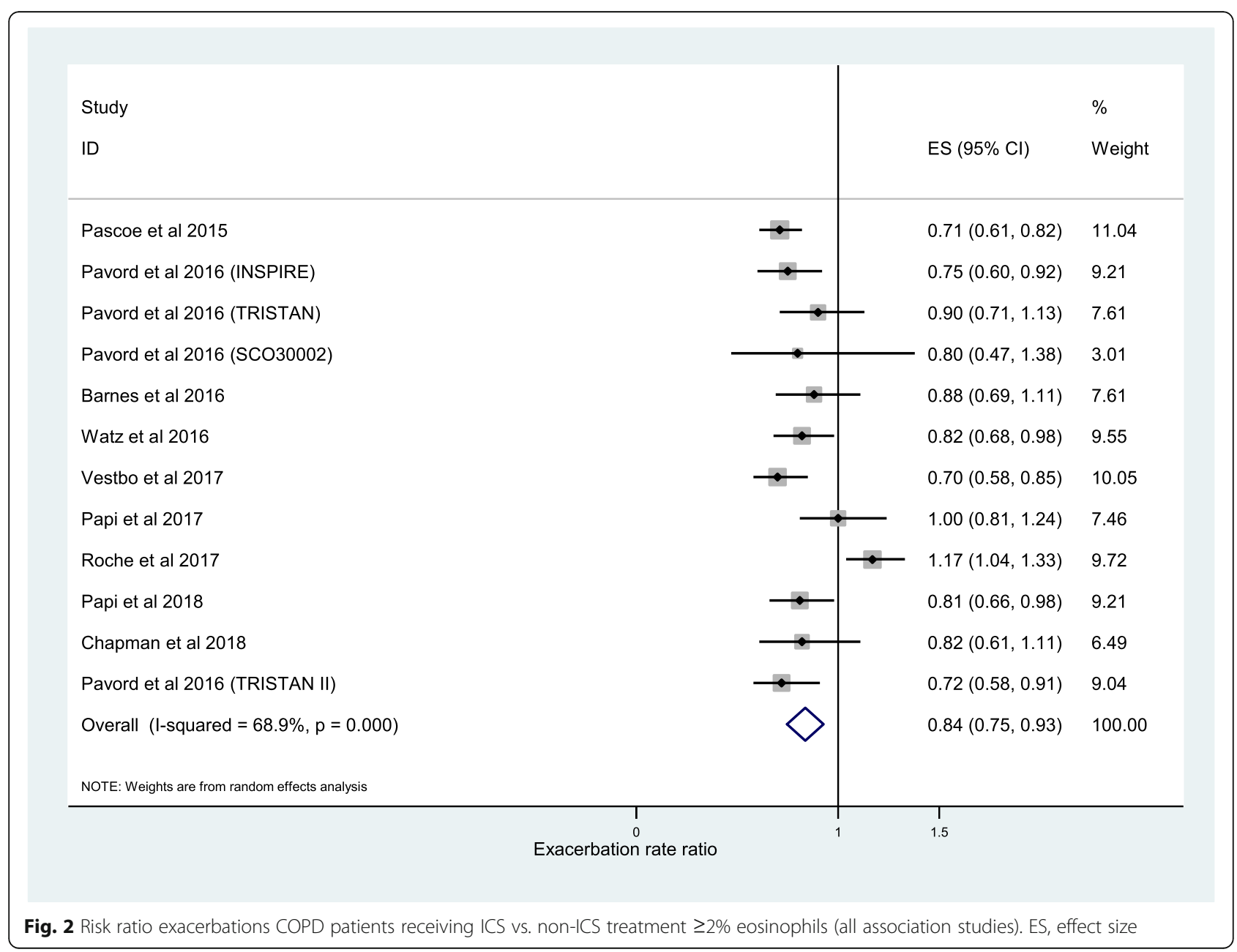


quality appraisal of the included studies and created the final quality appraisal by consensus.

\section{Inclusion criteria}

Data derived from published post-hoc analyses of randomised controlled trials (RCTs) and observational studies in primary or secondary care that reported the association, presented as a hazard ratio with confidence intervals, between blood eosinophil count, and the frequency of moderate or severe exacerbations in patients with COPD were included. Exacerbations were defined as COPD symptoms for which antibiotics or oral steroids were prescribed (moderate) or COPD symptoms for which hospital admission was recommended (severe). Included inhaled corticosteroids were beclometasone, budesonide, fluticasone (propionate and furoate), mometasone, ciclesonide, triamcinolone and flunisolide. Three blood eosinophil thresholds, 2\%, 150 cells $/ \mu \mathrm{L}$ and 300 cells $/ \mu \mathrm{L}$, were examined. Studies which exclusively examined other blood eosinophil thresholds were excluded, as were conference abstracts, reviews, reports and correspondence articles (Fig. 1).

\section{Data extraction}

Data were extracted from the relevant articles and included title and authors, year of publication, treatment regimens in each study arm, annual rate of moderate and severe exacerbations and blood eosinophil threshold used.

\section{Quality assessment}

The Cochrane Risk of Bias Tool [22] was used to assess the RCTs. The Newcastle-Ottawa scale [23] was used to assess the non-randomized observational studies. Two reviewers independently applied the risk of bias assessments to each included study. Any disagreement was resolved through discussion. We used the GRADE approach (grading of recommendations assessment, development, and evaluation) to assess the quality of the evidence for each outcome across the included studies [24].

\section{Meta-analysis}

The meta-analysis analysed the association between ICS prescription and risk of exacerbation for each of

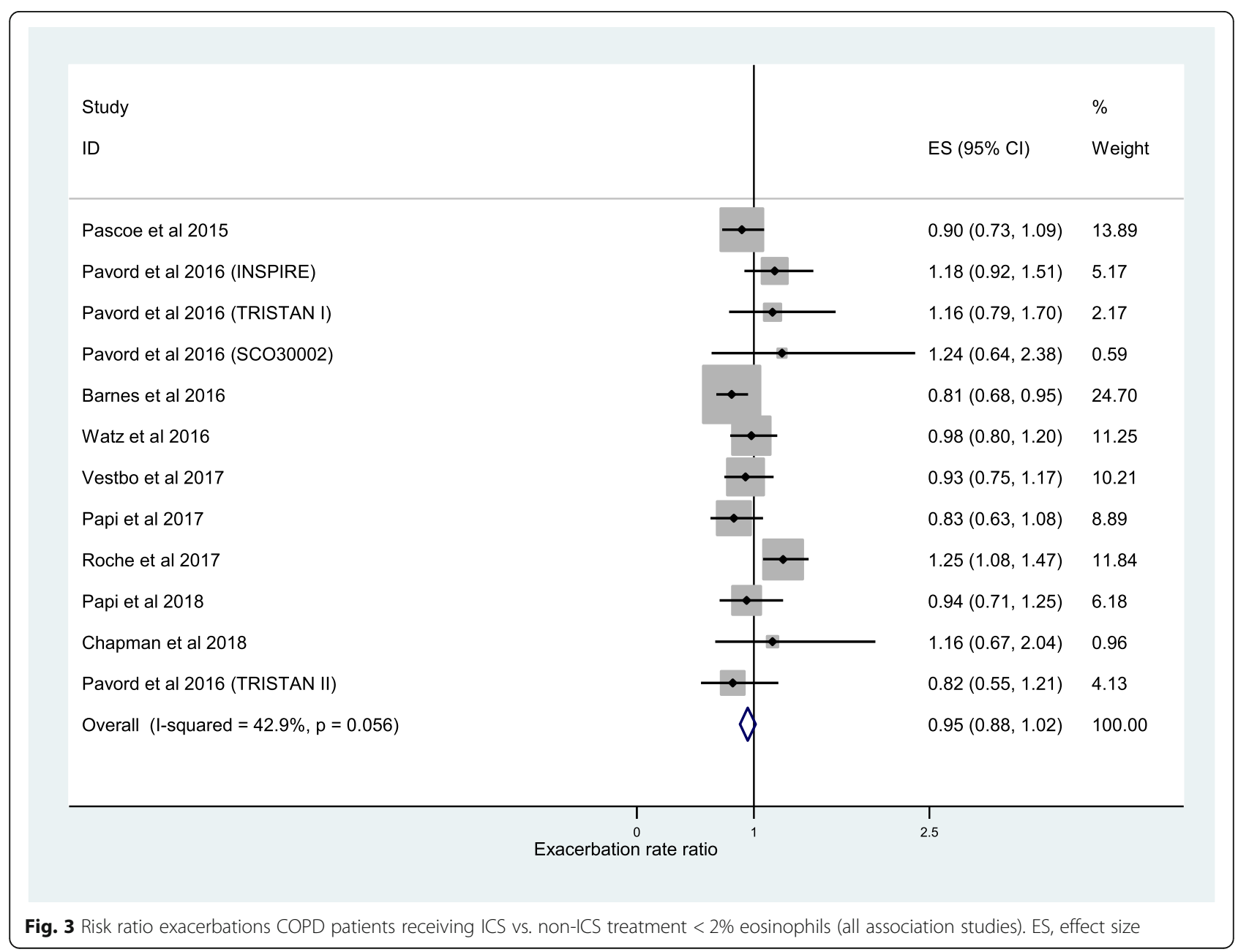


three blood eosinophil thresholds: $2 \%, 150$ cells $/ \mu \mathrm{L}$, 300 cells $/ \mu \mathrm{L}$. Our initial meta-analysis included studies of ICS vs. any non-ICS regimen. The comparison group may have included the effect of additional bronchodilator. Our further analysis examined the independent effect of ICS. It included studies of ICS vs. placebo or ICS + LABA vs. LABA or ICS + LABA+LAMA vs. LABA+LAMA.

We tested for between-study heterogeneity, where the true underlying effect varies between trials, using Cochran's Q. This was quantified using the $\mathrm{I}^{2}$ statistic, giving the proportion of overall variation accounted for by between-study heterogeneity. We also assessed clinical and methodological heterogeneity by discussion between authors. Where we judged there was important heterogeneity, we used a random effects analysis. Otherwise, we used a fixed-effects model that assumed each study measured the same underlying effect. The protocol for this review was registered with PROSPERO, with registration ID 2019 CRD42019134833.

\section{Results}

Five thousand five hundred eighty-three studies were identified and screened (Fig. 1 PRISMA flow chart). The full texts of 451 studies were assessed for eligibility. 16 studies fulfilled the inclusion criteria. Eleven of these studies [20, 25-34], comprising 25,881 patients, were post-hoc analyses of data from 13 RCTs (Table 1). The remaining 5 studies [35-39], comprising 109,704 patients, were retrospective observational studies (Table 2). Relevant data published from two post-hoc analyses of four RCTs were not presented in a form that could be incorporated in this review $[5,40]$. The data were sought from the companies holding the data but had not been received in time for inclusion in this review. Search strategies are included see Additional file 1: Tables S3, S4, S5, S6, S7 and S8.

The post-hoc analyses of RCTs were divided into those which had balanced treatment arms except for ICS, and those where one arm received an additional treatment (typically a LAMA). The independent effect of the ICS on risk of moderate or severe exacerbation was isolated in the RCTs which had balanced treatment arms [20, 25-28, 31-34] but not in those which did not $[26,29,30]$. One study [26] reported the results of three different RCTs: INSPIRE, TRISTAN and SCO30002. The INSPIRE study did not isolate the independent effect of the ICS whereas the TRISTAN and SCO30002 studies did. The TRISTAN study

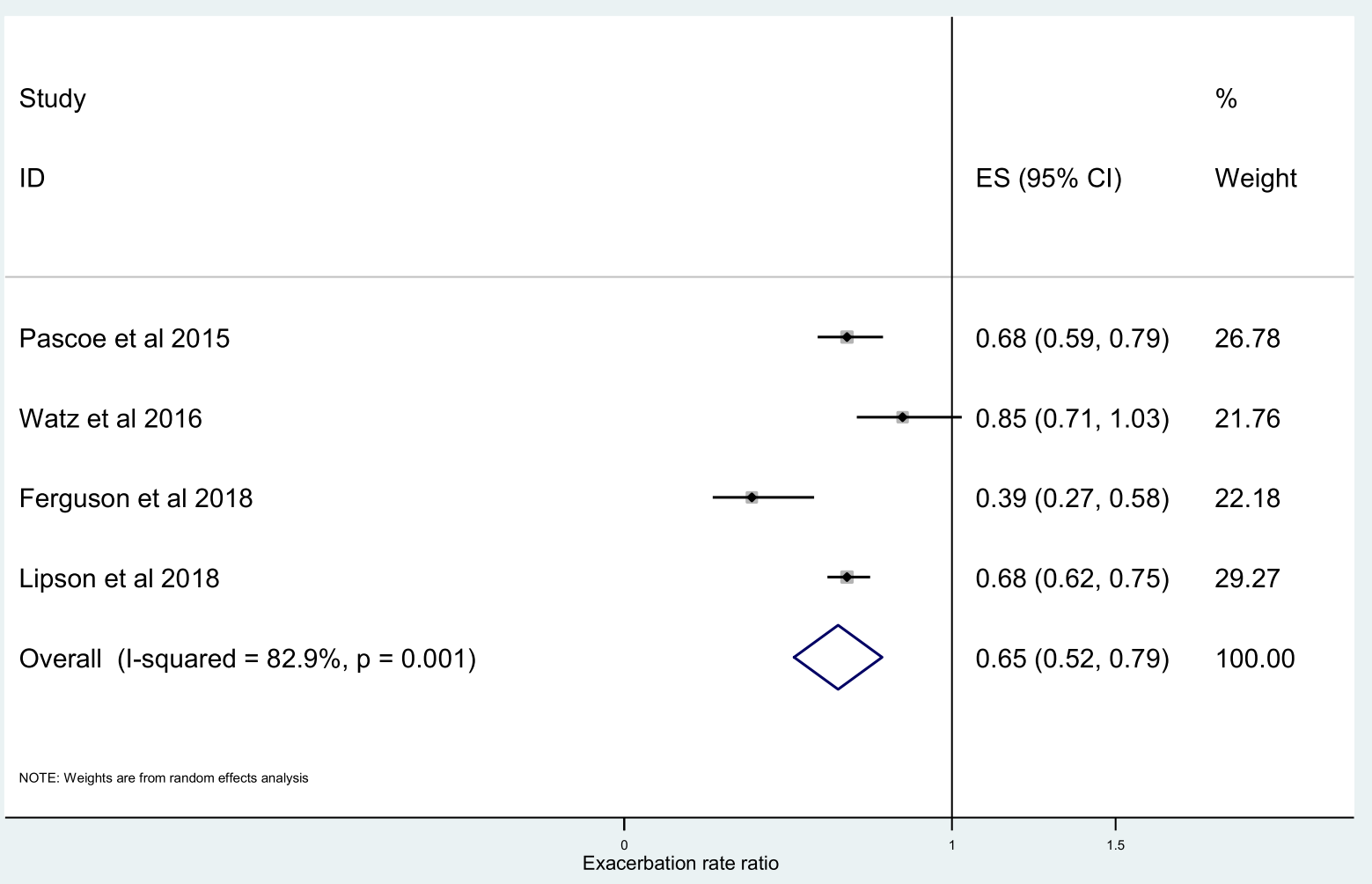

Fig. 4 Risk ratio exacerbations COPD patients receiving ICS vs. non-ICS treatment $\geq 150$ cells/ $\mu \mathrm{L}$ eosinophils (ICS-independent association studies). ES, effect size 
comprised five different drug comparisons. Two of these, Fluticasone propionate (FP) + Salmeterol (SAL) vs. SAL and FP vs. placebo, isolated the independent effect of the ICS. The patient groups in these two drug comparisons were mutually exclusive. These have been labelled here as TRISTAN I (FP/SAL vs. SAL) and TRISTAN II (FP vs. placebo) and treated as two separate investigations in the meta-analysis.

\section{Association between impact of ICS and blood eosinophil threshold}

The results of 11 studies taken from the post-hoc analyses of 13 RCTs were pooled for meta-analysis of the association between frequency of moderate or severe exacerbations and ICS use. We found that ICS treatment reduced exacerbations compared with no ICS for patients with $\geq 2 \%$ blood eosinophils (RR, 0.84; 95\% CI, 0.75-0.93) (Fig. 2). For patients with $<2 \%$ blood eosinophils we found no significant difference (RR, 0.95; $95 \%$ CI, 0.88-1.02) (Fig. 3). A significant difference was also observed at $\geq 150$ cells $/ \mu \mathrm{L}$ blood eosinophil threshold (RR, 0.65; 95\% CI, 0.52-0.79) (Fig. 4) and at < 150 cells/ $\mu \mathrm{L}$ blood eosinophil threshold (RR, 0.87; 95\% CI, 0.790.95 ) (Fig. 5) but not at $\geq 300$ cells $/ \mu \mathrm{L}$ blood eosinophil threshold (RR, 0.76; 95\% CI, 0.43-1.09) (Additional file 1: Figure S1).

The further analysis, among the studies that described the independent association between exacerbation frequency and ICS, demonstrated a significant difference between ICS treatment and non-ICS treatment at $<2 \%$ blood eosinophil threshold (RR, 0.89; 95\% CI, 0.81-0.97) (Fig. 6) and $<150$ cells $/ \mu \mathrm{L}$ blood eosinophil threshold (RR, 0.87; 95\% CI, 0.79-0.95) (Fig. 5). The independent effect of ICS on reduction in frequency of moderate or severe exacerbations was $20 \%$ at $\geq 2 \%$ blood eosinophil threshold (RR, 0.80; 95\% CI, 0.74-0.85) (Fig. 7), $35 \%$ at $\geq 150$ cells $/ \mu \mathrm{L}$ blood eosinophil threshold (RR, 0.65; 95\% CI, 0.52-0.79) (Fig. 4), and 39\% at $\geq 300$ cells/ $\mu \mathrm{L}$ blood eosinophil threshold (RR, 0.61; 95\% CI, 0.44-0.78) (Fig. 8). No difference was seen at $<300$ cells/ $\mu \mathrm{L}$ blood eosinophil threshold (RR, 0.98; 95\% CI, 0.82-1.14) (Fig. 9).

At the $2 \%$ blood eosinophil threshold we have presented the results of the pooled analysis of all studies and the further analysis of those studies which show the independent effect of ICS. We have presented only the results of the further analysis at the blood eosinophil thresholds of 150 cells $/ \mu \mathrm{L}$ and 300 cells $/ \mu \mathrm{L}$. The results

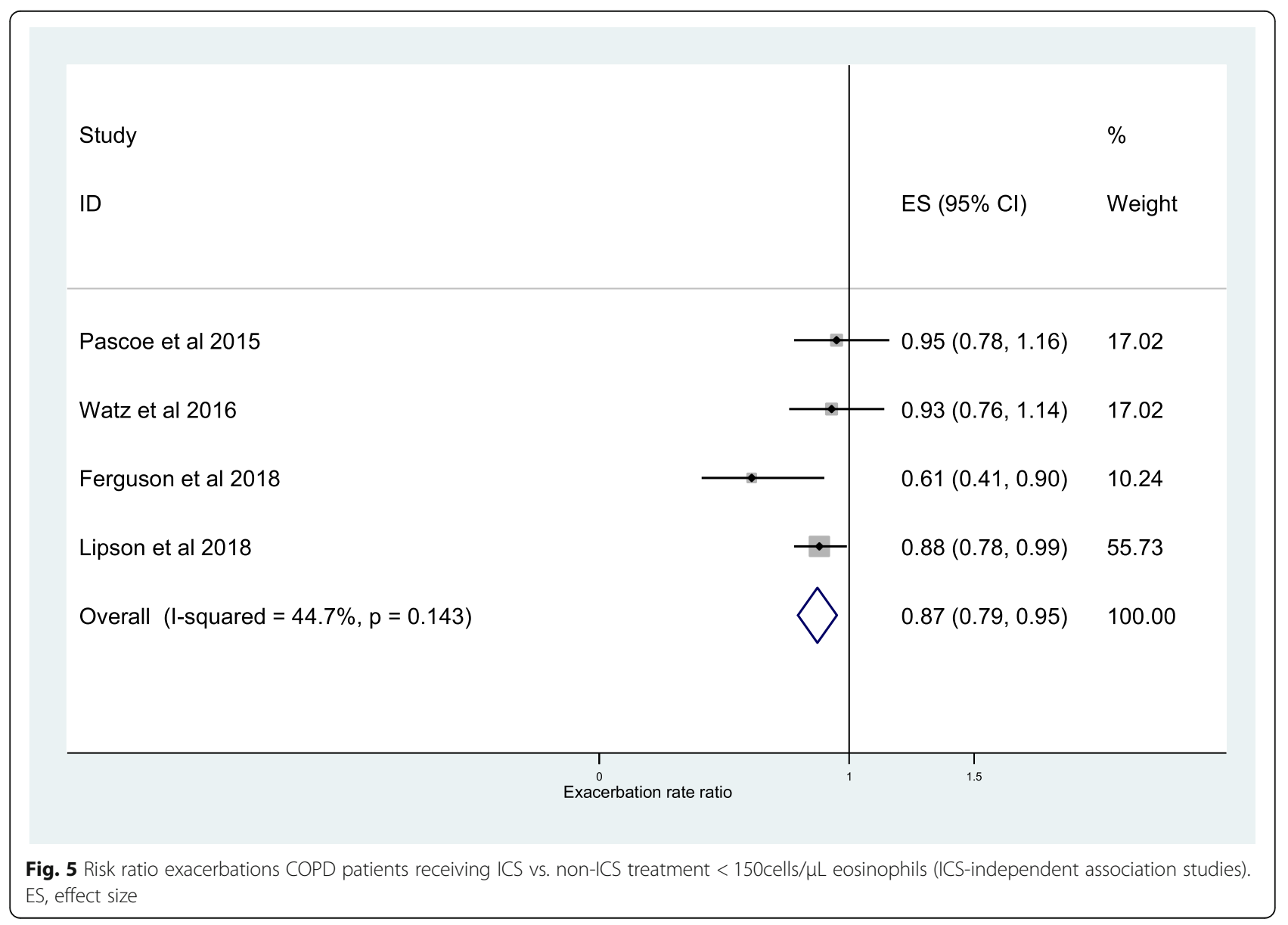




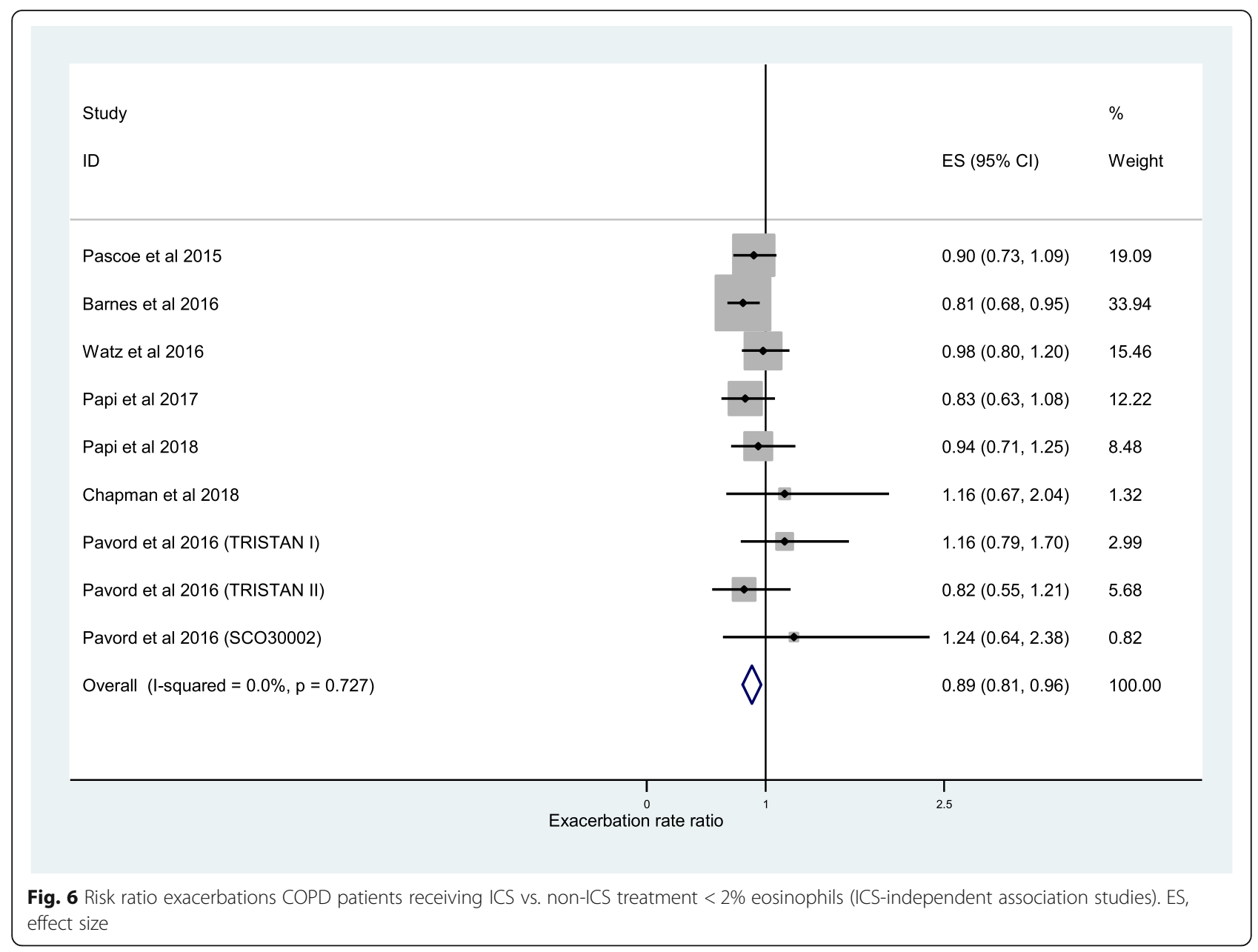

of the meta-analysis of all studies at $\geq 300$ cells $/ \mu \mathrm{L}$ blood eosinophil threshold, including those that did not isolate the independent effect of ICS, are given in the Additional file 1: Figure S1. The positive association and strength of the effect size was greatest when the independent effect of ICS was examined at the blood eosinophil thresholds of 150 cells $/ \mu \mathrm{L}$ and 300 cells $/ \mu \mathrm{L}$. We used a random-effects model, to calculate the pooled estimate accounting for heterogeneity, where we judged there was important heterogeneity. In each of these cases $p<0.1$ or $\mathrm{I}^{2}>50 \%$. Funnel plots from each analysis are presented in Additional file 1: Figures S2, S3, S4, S5, S6, S7, S8, S9 and S10.

\section{Observational studies}

Suissa et al. reported that patients with blood eosinophils of $\geq 4 \%$ who were initiated on LABA + ICS had $21 \%$ fewer moderate or severe exacerbations noted in the record compared to those patients initiated on a LAMA (RR, 0.79; 95\% CI, 0.70-0.88) [36]. In the same study, in patients with blood eosinophils of $\geq 300 / \mu \mathrm{L}$ the risk of an exacerbation noted in the record was 24\% (RR, 0.76; 95\% CI, 0.67-0.85) lower. No association was found between blood eosinophil count and impact of ICS on exacerbation frequency in any of the other observational studies [35, 37-39].

\section{Quality assessment}

The risk of bias assessment of the post-hoc analysis of the RCTs is presented in Additional file 1: Table S1. The RCTs were at low risk of bias for random sequence generation and performance bias. Five studies had unclear detection bias and six studies had either unclear or high risk of attrition bias. Six studies had unclear risk of reporting bias. The GRADE assessment identified the quality of evidence for the association between blood eosinophil count and the response of exacerbation risk to ICS, in COPD patients as low at blood eosinophil thresholds $\geq 2 \%$ and $\geq 150$ cells $/ \mu \mathrm{L}$ and as very low at blood eosinophil threshold $\geq 300$ cells $/ \mu \mathrm{L}$ (Additional file 1: Table S2). The results of the quality assessment of the observational studies are 


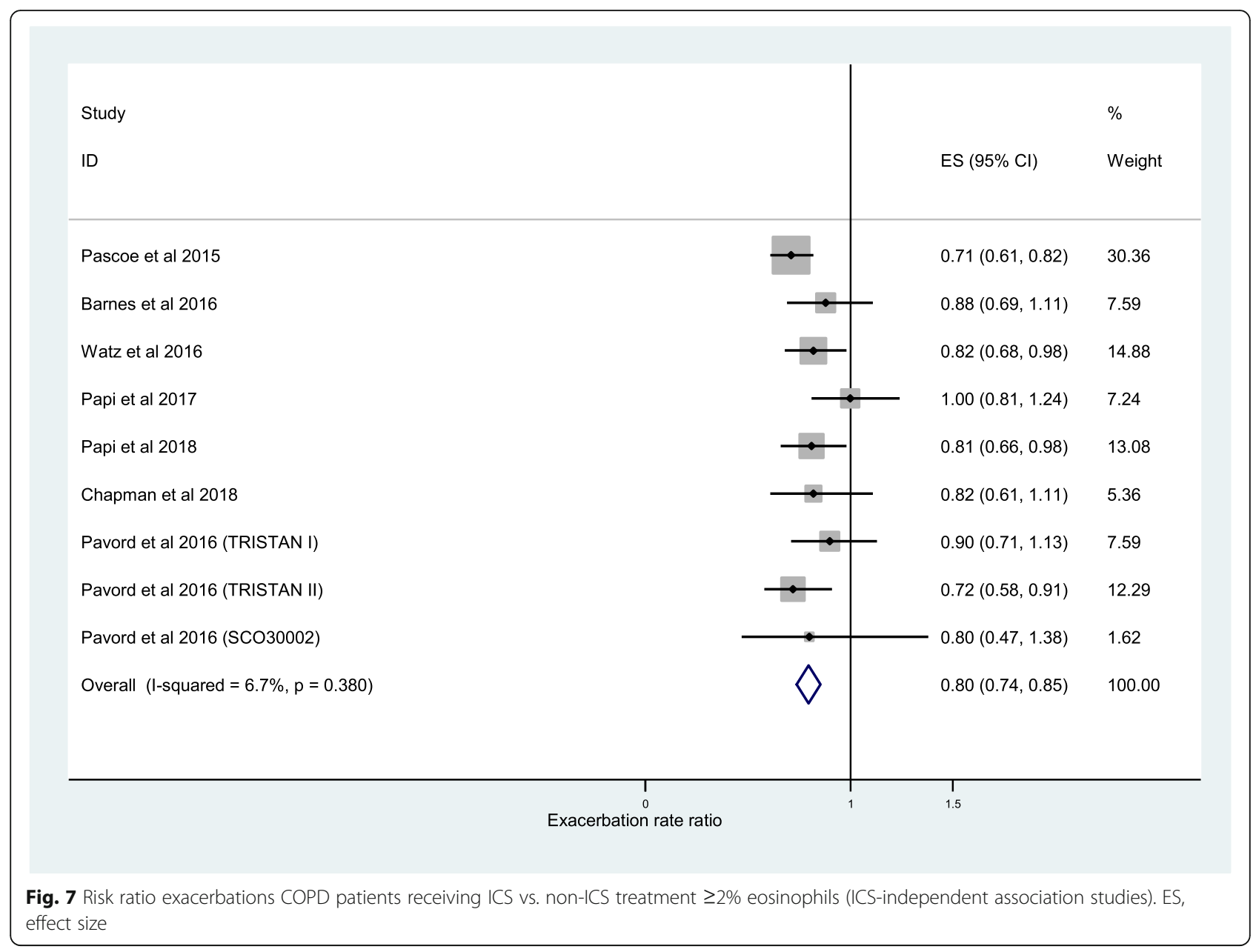

presented in Additional file 1: Table S3. The studies were of a uniform high quality.

\section{Discussion}

Our meta-analysis has identified a positive association between use of ICS and risk of moderate or severe COPD exacerbations when stratified by blood eosinophil threshold. When all studies were examined the positive association was present at $\geq 2 \%$ and $\geq 150$ cells/ $\mu \mathrm{L}$ eosinophil thresholds, but not at the $\geq 300$ cells $/ \mu \mathrm{L}$ threshold. When the independent effect of ICS was isolated the association was positive at each of the three thresholds and the degree of the association/effect size had increased. The evidence for the association at each of these thresholds was low or very low.

A lack of association between use of ICS and risk of moderate or severe COPD exacerbations was found in 4 of the 5 observational studies [35, 37-39]. Reasons for the difference in results between the two types of studies may include differences in patient demographics, or differences between bronchodilator use by participants of the RCTs compared to those of the observational studies. The results of the observational studies may be less reliable than those of the RCTs due to differences in quality between the two types of studies. It has been estimated that those patients with COPD selected for clinical trials are representative of about $7 \%$ of the entire COPD population [41].

Eleven of the 13 RCTs recruited only patients with a history of $\geq 1$ exacerbation in the past 12 months. In three of the observational studies $[35,36,39]$ the proportion of patients reported to have experienced $\geq 1$ exacerbation in the past 12 months was between $32 \& 41 \%$. The remaining two observational studies excluded patients who had experienced an exacerbation either in the 6 months prior to the index date [38] or at any point in the past [37]. COPD patients with the greatest degree of airflow impairment may experience the largest number of exacerbations. All of the RCTs recruited patients with either severe to very severe airflow limitation $[27,32]$ or moderate to severe airflow limitation. In 3 of the $5 \mathrm{ob}$ servational studies the disease severity of the patients was unknown [36-38]. Participants in the remaining 2 observational studies had a mean FEV1\% predicted of > 


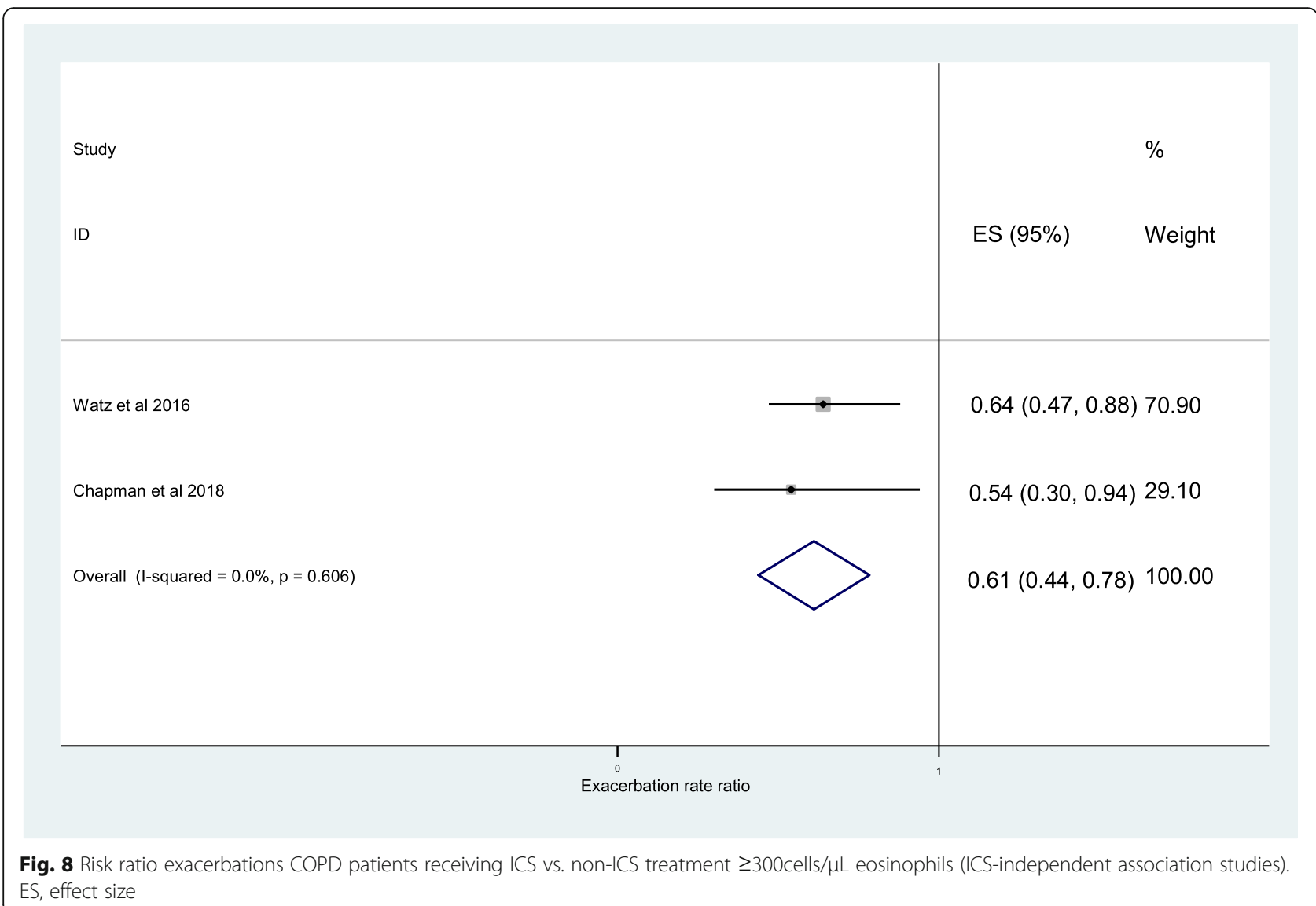

$50 \%[35,39]$. The severity of airflow limitation of patients in the RCTs is likely to have been greater and their baseline exacerbation prevalence higher than those in the observational studies. The effect of ICS use is likely to be more apparent within the RCTs in comparison to the observational studies.

One potential explanation of the disparity in results could be a higher rate of undiagnosed asthma among the participants of the RCTs compared with the observational studies. Patients with a current diagnosis of asthma were excluded in all but one of the RCTs [20, 26-34]. Three RCTs recruited patients who may have had a past diagnosis of asthma [20,28,34]. Eleven RCTs undertook reversibility testing $[20,25,26,29-34]$ and 4 of these RCTs excluded patients with a reversibility of > $10 \%[25,26]$. The remaining 7 RCTs $[20,29-34]$ included patients with reversibility, an indicator of asthma, their prevalence ranging from 10 to $25 \%$. In 4 of 5 observational studies participants with an asthma diagnosis were excluded [35, 37-39]. The one observational study that did not exclude patients with asthma found a positive association at blood eosinophil thresholds $\geq 4 \%$ and $\geq$ 300 cells $/ \mu \mathrm{L}$ between use of LABA + ICS and a decrease in exacerbation frequency, compared to use of LAMA [36]. It is probable that both the RCTs and observational studies included a proportion of patients with asthma/ reversibility, in whom the association between ICS use and reduction in exacerbation risk would be strongest. A baseline blood eosinophil count of $\geq 500$ cells $/ \mu \mathrm{L}$ has been identified in $30 \%$ of patients with asthma [42] but in only $3.3 \%$ of patients with COPD [17]. The FLAME study, one of the few RCTs which failed to find an association between eosinophil count and impact of ICS in COPD patients, excluded those patients with blood eosinophils $\geq 600$ cells/ $\mu \mathrm{L}$ [30].

Use of concurrent bronchodilators among patients in the observational studies, but not those of the RCTs, may have contributed to the lack of association found between ICS use and risk of exacerbations in the observational studies. The findings of the observational studies raise questions about the transferability of the post-hoc RCT findings to real world clinical practice. A strong association between impact of ICS and risk of exacerbations at the three eosinophil thresholds was evident from the meta-analysis. Any new prospective trial with randomization by eosinophil status is unlikely to come up with an assessment of efficacy of ICS in preventing exacerbations in COPD in patients above the experimental threshold that gives a different result. However, the observational studies do suggest that the 


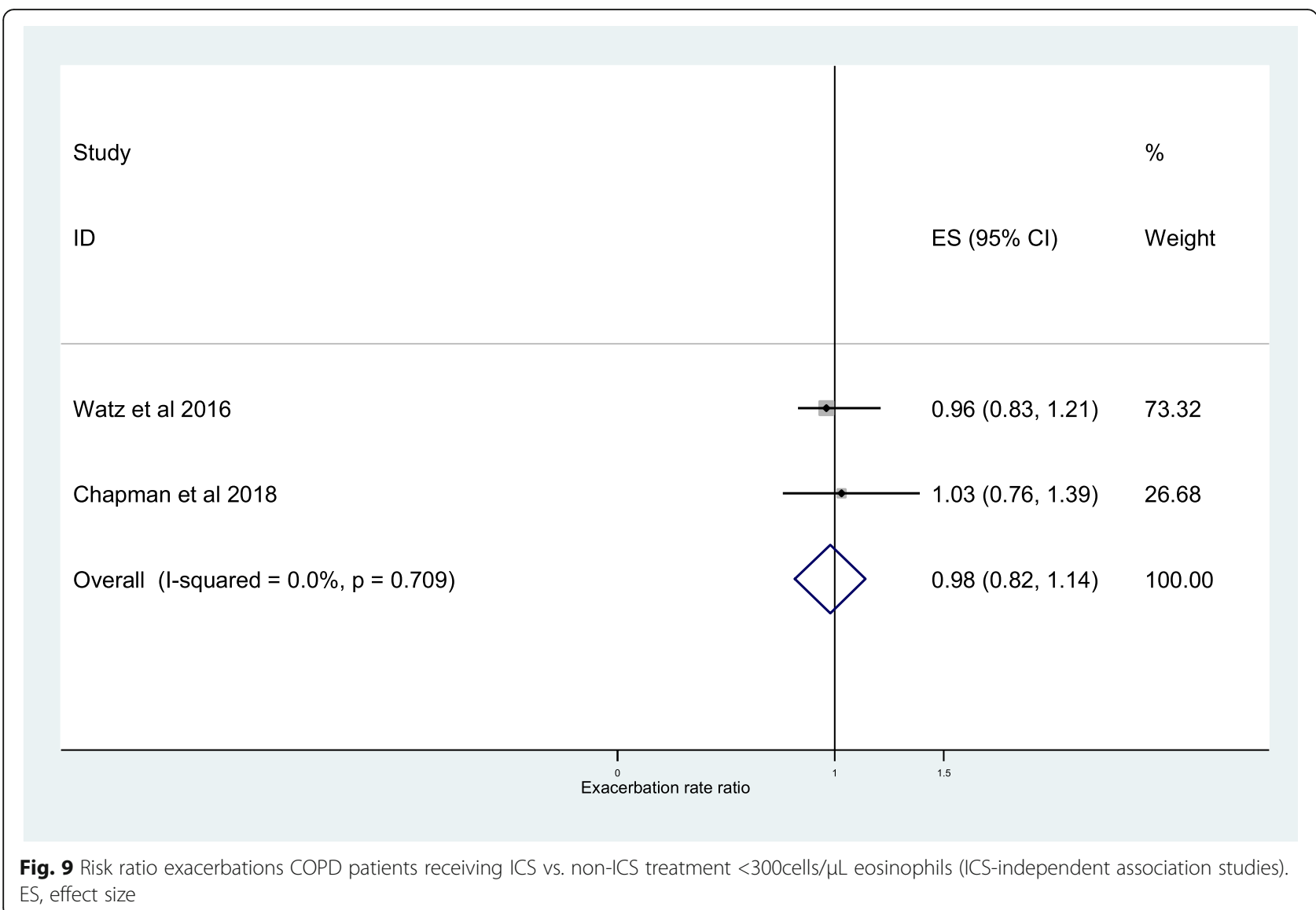

effectiveness of ICS using the eosinophil threshold of $2 \%$ (or 150 cells $/ \mu \mathrm{L}$ ) in a real-world setting cannot be assumed from efficacy trials. An effectiveness trial, which excludes patients with asthma, may help in answering this question. A limitation of the observational studies is the lack of consistency in the reporting of concurrent bronchodilator use among participants. However, it is exactly these factors together with differences in clinical and demographic characteristics that make effectiveness trials so important in testing the applicability of efficacy trials which have such tight inclusion and exclusion criteria as drug trials in COPD.

This review has examined the predictive value of blood eosinophils on the impact of ICS when patients are stratified by both relative and absolute blood eosinophil counts. The relative blood eosinophil count will be altered by the numbers of other cells within the white blood cell population. This suggests that the relative blood eosinophil count is inherently less reliable than the absolute blood eosinophil count. Despite this we have identified a positive association at raised thresholds of both the relative and absolute blood eosinophil counts.

GOLD guidelines recommend escalation from dual LABA+LAMA therapy to LABA+ICS in patients with blood eosinophil counts $\geq 300$ cells $/ \mu \mathrm{L}$ or in those with blood eosinophils of $\geq 100$ cells $/ \mu \mathrm{L}$ and a history of $\geq 2$ exacerbations or 1 severe exacerbation [8]. The metaanalysis by Oshagbemi et al. identified a positive association between ICS use and reduction in exacerbation risk at blood eosinophil thresholds of $\geq 100$ to $\geq 340$ cells/ $\mu \mathrm{L}$ [7]. They did not stratify the results into narrower eosinophil ranges, nor did they differentiate by past exacerbation history. The effect, or lack of effect of ICS on exacerbation risk at low eosinophil thresholds may have been over-ridden by the effect seen at higher eosinophil thresholds. Their findings confirm the GOLD recommendation for use of ICS at eosinophil threshold $\geq 300$ cells $/ \mu \mathrm{L}$ but do not directly justify use at eosinophil threshold $\geq 100$ cells $/ \mu \mathrm{L}$ accompanied by a history of $\geq 2$ exacerbations or 1 severe exacerbation. Bafadhel et al. described a continuous relationship between blood eosinophil count and the impact of budesonide on reduction in exacerbation risk [5]. At eosinophil counts of < 200 cells $/ \mu \mathrm{L}$ the confidence intervals were broad and the upper limit close to one.

The blood eosinophil count may help characterize the nature of exacerbations within a population of patients with COPD who experience exacerbations. Its value is less clear for those patients with COPD who do not have 
exacerbations. The eosinophil count may be elevated for other reasons including allergies, inflammatory conditions and malignancies. In addition, a single blood eosinophil count may be an unsatisfactory basis upon which to prescribe ICS.

\section{Conclusion}

This meta-analysis has demonstrated a positive association and a strong effect size, across three blood eosinophil thresholds $-2 \%, 150$ cells $/ \mu \mathrm{L}$ and 300 cells $/ \mu \mathrm{L}$, between ICS, independently assessed, and the risk of an exacerbation of COPD. The strength of the association was less when the contributory effects of the bronchodilators were not excluded. The strength of the association increased as the blood eosinophil threshold increased. The quality of the evidence for these associations was low or very low. Data from the post-hoc RCTs may not justify extrapolation to the general COPD population. The lack of association found in the observational studies suggests that this relationship may not be present within the "real world" COPD population. A prospective effectiveness study which differentiates patients according to past exacerbation history and reversibility of lung function and stratified by ranges of eosinophil counts rather than eosinophil thresholds should be conducted.

\section{Supplementary information}

Supplementary information accompanies this paper at https://doi.org/10. 1186/s12931-019-1268-7.

Additional file 1: Figure S1. Forest plot of risk ratio exacerbations COPD patients receiving ICS vs. non-ICS treatment $\geq 300$ cells $/ \mu \mathrm{L}$ eosinophils (all association studies). Figures S2 to S10. Funnel plots of all studies for each of the outcomes at the three eosinophil thresholds. Table S1. Risk of bias summary of post-hoc RCTs. Table S2. GRADE assessment of outcomes from post-hoc RCTs. Table S3. NewcastleOttawa Quality Assessment Scale for Observational Cohort Studies. Tables S4 to S8. Database search results.

\section{Abbreviations}

COPD: Chronic obstructive pulmonary disease; FP: Fluticasone propionate; GOLD: Global Initiative for Chronic Obstructive Lung Disease;

GRADE: Grading of recommendations assessment, development, and evaluation; ICS: Inhaled corticosteroids; LABA: Long-acting beta-agonist; LAMA: Long-acting muscarinic antagonist; MeSH: Medical Subject Heading; PRISMA: Preferred Reporting Items for Systematic Reviews and Meta-Analysis; RCT: Randomised controlled trial; SAL: Salmeterol

\section{Acknowledgements}

Not applicable.

\section{Authors' contributions}

THH, PW, CC, DA, IJM devised the study. LM and VP assisted in devising and reviewing the search strategies. THH, PW, VR undertook the searching and review of papers. PS and DA provided statistical assistance and advice. All authors contributed to the review and approval of the final manuscript.

\section{Funding}

THH is supported by a National Institute for Health Research (NIHR) Doctoral Research Fellowship. VP is supported by a National Institute for Health Research (NIHR) Clinical Lectureship. LM is supported by a National Institute for Health Research (NIHR) In-Practice Fellowship. IJM is supported by the UK Medical Research Council (MRC) through its Skills Development Fellowship program, grant MR/N015185/1.

\section{Availability of data and materials}

All data generated or analysed during this study are included in this published article [and its supplementary information files].

Ethics approval and consent to participate

Not applicable.

\section{Consent for publication}

Not applicable.

\section{Competing interests}

The authors declare that they have no competing interests.

\section{Author details}

${ }^{1}$ Department of Public Health and Primary Care, School of Population Health \& Environmental Sciences, King's College London, 3rd floor Addison House, Guys Campus, London SE1 1UL, UK. ²Department of Asthma Allergy \& Respiratory Science, King's College London, London, UK.

Received: 28 September 2019 Accepted: 23 December 2019

Published online: 03 January 2020

\section{References}

1. Yang IA, Clarke MS, Sim EHA, Fong KM. Inhaled corticosteroids for stable chronic obstructive pulmonary disease. Cochrane Database Syst Rev Online. 2012:7:CD002991.

2. Bafadhel M, McKenna S, Terry S, Mistry V, Reid C, Haldar P, et al. Acute exacerbations of chronic obstructive pulmonary disease. Am J Respir Crit Care Med. 2011;184(6):662-71.

3. Siva R, Green RH, Brightling CE, Shelley M, Hargadon B, McKenna S, et al. Eosinophilic airway inflammation and exacerbations of COPD: a randomised controlled trial. Eur Respir J. 2007:29(5):906-13.

4. Pavord ID, Bafadhel M. Exhaled nitric oxide and blood eosinophilia: independent markers of preventable risk. J Allergy Clin Immunol. 2013; 132(4):828-9.

5. Bafadhel M, Peterson S, De Blas MA, Calverley PM, Rennard SI, Richter K, et al. Predictors of exacerbation risk and response to budesonide in patients with chronic obstructive pulmonary disease: a post-hoc analysis of three randomised trials. Lancet Respir Med. 2018:6(2):117-26.

6. Cazzola M, Rogliani P, Calzetta L, Matera MG. Triple therapy versus single and dual long-acting bronchodilator therapy in COPD: a systematic review and meta-analysis. Eur Respir J. 2018;52(6):1801586.

7. Oshagbemi OA, Odiba JO, Daniel A, Yunusa I. Absolute blood eosinophil counts to guide inhaled corticosteroids therapy among patients with COPD: systematic review and meta-analysis. Curr Drug Targets. 2019;20(16):1679-0.

8. Global Initiative for Chronic Obstructive Pulmonary Disease. Global strategy for the diagnosis, management, and prevention of chronic obstructive pulmonary disease: Global Initiative for Chronic Obstructive Pulmonary Disease, Inc; 2019. www.goldcopd.com

9. Schleich F, Corhay J-L, Louis R. Blood eosinophil count to predict bronchial eosinophilic inflammation in COPD. Eur Respir J. 2016;47(5):1562-4.

10. Bafadhel M, Pavord ID, Russell REK. Eosinophils in COPD: just another biomarker? Lancet Respir Med. 2017;5(9):747-59.

11. Singh D, Kolsum U, Brightling CE, Locantore N, Agusti $A$, Tal-Singer $R$, et al, Eosinophilic inflammation in COPD: prevalence and clinical characteristics. Eur Respir J. 2014:44(6):1697-700.

12. Cheng S-L. Blood eosinophils and inhaled corticosteroids in patients with COPD: systematic review and meta-analysis. Int J Chron Obstruct Pulmon Dis. 2018;13:2775-84.

13. White P, Thornton H, Pinnock H, Georgopoulou S, Booth HP. Overtreatment of COPD with inhaled corticosteroids - implications for safety and costs: cross-sectional observational study. PLoS One. 2013;8(10):e75221.

14. Harries TH, Seed PT, Jones S, Schofield P, White P. Chronic obstructive pulmonary disease hospital admissions and drugs--unexpected positive associations: a retrospective general practice cohort study. NPJ Prim Care Respir Med. 2014;24:14006 
15. Harries TH, Thornton H, Crichton S, Schofield P, Gilkes A, White PT. Hospital readmissions for COPD: a retrospective longitudinal study. NPJ Prim Care Respir Med. 2017;27(1):31.

16. Schumann DM, Tamm M, Kostikas K, Stolz D. Stability of the Blood Eosinophilic Phenotype in Stable and Exacerbated COPD. Chest. 2019;156(3): 456-65.

17. Turato $G$, Semenzato $U$, Bazzan $E$, Biondini $D$, Tinè $M$, Torrecilla $N$, et al. Blood Eosinophilia Neither Reflects Tissue Eosinophils nor Worsens Clinical Outcomes in Chronic Obstructive Pulmonary Disease. Am J Respir Crit Care Med. 2018;197(9):1216-9.

18. Hospers JJ, Schouten JP, Weiss ST, Rijcken B, Postma DS. Asthma attacks with eosinophilia predict mortality from chronic obstructive pulmonary disease in a general population sample. Am J Respir Crit Care Med. 1999; 160(6):1869-74.

19. Bafadhel M, Davies L, Calverley PMA, Aaron SD, Brightling CE, Pavord ID. Blood eosinophil guided prednisolone therapy for exacerbations of COPD: a further analysis. Eur Respir J. 2014;44(3):789-91.

20. Pascoe S, Locantore N, Dransfield MT, Barnes NC, Pavord ID. Blood eosinophil counts, exacerbations, and response to the addition of inhaled fluticasone furoate to vilanterol in patients with chronic obstructive pulmonary disease: a secondary analysis of data from two parallel randomised controlled trials. Lancet Respir Med. 2015;3(6):435-42.

21. Moher D, Liberati A, Tetzlaff J, Altman DG, PRISMA group. Preferred reporting items for systematic reviews and meta-analyses: the PRISMA statement. BMJ. 2009;339:b2535.

22. Higgins JPT, Altman DG, Gøtzsche PC, Jüni P, Moher D, Oxman AD, et al. The Cochrane Collaboration's tool for assessing risk of bias in randomised trials. BMJ. 2011;343:d5928.

23. Wells G, Shea B, O'Connell D, Peterson J, Welch V, Losos M, et al. The Newcastle-Ottawa Scale (NOS) for assessing the quality if nonrandomized studies in meta-analyses. [Internet]. Available from: http://www.ohri.ca/ programs/clinical_epidemiology/oxford.htm

24. Guyatt G, Oxman AD, Akl EA, Kunz R, Vist G, Brozek J, et al. GRADE guidelines: 1. Introduction-GRADE evidence profiles and summary of findings tables. J Clin Epidemiol. 2011;64(4):383-94.

25. Barnes NC, Sharma R, Lettis S, Calverley PMA. Blood eosinophils as a marker of response to inhaled corticosteroids in COPD. Eur Respir J. 2016;47(5): 1374-82.

26. Pavord ID, Lettis S, Locantore N, Pascoe S, Jones PW, Wedzicha JA, et al. Blood eosinophils and inhaled corticosteroid/long-acting $\beta$-2 agonist efficacy in COPD. Thorax. 2016;71(2):118-25.

27. Watz H, Tetzlaff K, Wouters EFM, Kirsten A, Magnussen H, Rodriguez-Roisin $R$, et al. Blood eosinophil count and exacerbations in severe chronic obstructive pulmonary disease after withdrawal of inhaled corticosteroids: a post-hoc analysis of the WISDOM trial. Lancet Respir Med. 2016;4(5):390-8.

28. Papi A, Dokic D, Tzimas W, Mészáros I, Olech-Cudzik A, Koroknai Z, et al. Fluticasone propionate/formoterol for COPD management: a randomized controlled trial. Int J Chron Obstruct Pulmon Dis. 2017;12:1961-71.

29. Vestbo J, Papi A, Corradi M, Blazhko V, Montagna I, Francisco C, et al. Single inhaler extrafine triple therapy versus long-acting muscarinic antagonist therapy for chronic obstructive pulmonary disease (TRINITY): a double-blind, parallel group, randomised controlled trial. Lancet. 2017;389(10082):1919-29.

30. Roche N, Chapman KR, Vogelmeier CF, Herth FJF, Thach C, Fogel R, et al. Blood Eosinophils and Response to Maintenance Chronic Obstructive Pulmonary Disease Treatment. Data from the FLAME Trial. Am J Respir Crit Care Med. 2017;195(9):1189-97

31. Chapman KR, Hurst JR, Frent S-M, Larbig M, Fogel R, Guerin T, et al. Longterm triple therapy De-escalation to Indacaterol/Glycopyrronium in patients with chronic obstructive pulmonary disease (SUNSET): a randomized, double-blind, triple-dummy clinical trial. Am J Respir Crit Care Med. 2018; 198(3):329-39.

32. Papi A, Vestbo J, Fabbri L, Corradi M, Prunier H, Cohuet G, et al. Extrafine inhaled triple therapy versus dual bronchodilator therapy in chronic obstructive pulmonary disease (TRIBUTE): a double-blind, parallel group, randomised controlled trial. Lancet. 2018;391(10125):1076-84.

33. Ferguson GT, Rabe KF, Martinez FJ, Fabbri LM, Wang C, Ichinose $M$, et al. Triple therapy with budesonide/glycopyrrolate/formoterol fumarate with cosuspension delivery technology versus dual therapies in chronic obstructive pulmonary disease (KRONOS): a double-blind, parallel-group, multicentre, phase 3 randomised controlled trial. Lancet Respir Med. 2018;6(10):747-58.
34. Lipson DA, Barnhart F, Brealey N, Brooks J, Criner GJ, Day NC, et al. Oncedaily single-inhaler triple versus dual therapy in patients with COPD. N Engl J Med. 2018;378(18):1671-80.

35. Song JH, Lee $\mathrm{C}-\mathrm{H}$, Kim JW, Lee $W-Y$, Jung JY, Park JH, et al. Clinical implications of blood eosinophil count in patients with non-asthma-COPD overlap syndrome COPD. Int J Chron Obstruct Pulmon Dis. 2017;12:2455-64.

36. Suissa S, Dell'Aniello S, Ernst P. Comparative effectiveness of LABA-ICS versus LAMA as initial treatment in COPD targeted by blood eosinophils: a population-based cohort study. Lancet Respir Med. 2018;6(11):855-62.

37. Oshagbemi OA, Franssen FME, Braeken DCW, Henskens Y, Wouters EFM. Maitland-van der zee A-H, et al. blood eosinophilia, use of inhaled corticosteroids, and risk of COPD exacerbations and mortality. Pharmacoepidemiol Drug Saf. 2018;27(11):1191-9.

38. Oshagbemi OA, Franssen FME, van Kraaij S, Braeken DCW, Wouters EFM, Maitland-van der Zee AH, et al. Blood Eosinophil Counts, Withdrawal of Inhaled Corticosteroids and Risk of COPD Exacerbations and Mortality in the Clinical Practice Research Datalink (CPRD). COPD. 2019;16(2):152-9.

39. Suissa S, Dell'Aniello S, Ernst P. Comparative effectiveness and safety of LABA-LAMA vs LABA-ICS treatment of COPD in real-world clinical practice. Chest. 2019;155(6):1158-65.

40. Siddiqui SH, Guasconi A, Vestbo J, Jones P, Agusti A, Paggiaro P, et al. Blood Eosinophils: a biomarker of response to Extrafine Beclomethasone/ Formoterol in chronic obstructive pulmonary disease. Am J Respir Crit Care Med. 2015;192(4):523-5.

41. Herland K, Akselsen J-P, Skjønsberg OH, Bjermer L. How representative are clinical study patients with asthma or COPD for a larger 'real life' population of patients with obstructive lung disease? Respir Med. 2005;99(1):11-9.

42. Ortega HG, Yancey SW, Mayer B, Gunsoy NB, Keene ON, Bleecker ER, et al. Severe eosinophilic asthma treated with mepolizumab stratified by baseline eosinophil thresholds: a secondary analysis of the DREAM and MENSA studies. Lancet Respir Med. 2016;4(7):549-56.

\section{Publisher's Note}

Springer Nature remains neutral with regard to jurisdictional claims in published maps and institutional affiliations.

Ready to submit your research? Choose BMC and benefit from:

- fast, convenient online submission

- thorough peer review by experienced researchers in your field

- rapid publication on acceptance

- support for research data, including large and complex data types

- gold Open Access which fosters wider collaboration and increased citations

- maximum visibility for your research: over $100 \mathrm{M}$ website views per year

At BMC, research is always in progress.

Learn more biomedcentral.com/submissions 